Commentary

\title{
Governance by Numbers: A Panopticon Reversed?
}

\author{
Julian Hamann \\ Leibniz Center for Science and Society, Leibniz University Hannover, 30159 Hannover, Germany; \\ E-Mail: julian.hamann@Icss.uni-hannover.de
}

Submitted: 8 March 2019 | Accepted: 16 March 2020 | Published: 9 April 2020

\begin{abstract}
This commentary is concerned with a specific form of power and discipline that is exerted through governance by numbers. Because of its many parallels to classical Foucauldian panopticism, governance based on numbers can be coined 'numerocratic panopticism.' Yet, going beyond similarities between classical and numerocratic panopticism, the commentary suggests three features specific to numerocratic panopticism that actually reverse characteristic traits of classical panopticism: In contrast to classical panopticism, numerocratic panopticism is multi-centered, non-spatial and open-purpose. Research on governance by numbers can benefit from a heuristic of panopticism if it considers both similarities and differences between classical and numerocratic panopticism.
\end{abstract}

\section{Keywords}

discipline; dispositif; Foucault; numerocracy; panopticon; power; quantification; surveillance

\section{Issue}

This commentary is part of the issue "Quantifying Higher Education: Governing Universities and Academics by Numbers" edited by Maarten Hillebrandt (University of Helsinki, Finland) and Michael Huber (University of Bielefeld, Germany).

(C) 2020 by the author; licensee Cogitatio (Lisbon, Portugal). This article is licensed under a Creative Commons Attribution 4.0 International License (CC BY).

\section{Introduction}

In the wake of New Public Management, public service sectors are increasingly governed by numbers. The cold, rational gaze of indicators, metrics and algorithms is supposed to increase productivity and efficiency and facilitate transparency and accountability. This new governance landscape also seizes the higher education sector: Governance based on numbers is developed and enforced by political stakeholders and media corporations and employed at different levels from the state to the university to individual departments. The contributions to this thematic issue survey this landscape. Krüger (2020), Hillebrandt (2020), and Kandiko Howson and Buckley (2020) illustrate how increasingly extensive and elaborate data infrastructures are becoming an end in themselves. The contributions by Dix, Kaltenbrunner, Tijdink, Valkenburg, and de Rijcke (2020) and Huber (2020) show how performance-based budgeting and quality assurance schemes direct universities, departments and researchers toward new objectives. Ringel, Brankovic, and Werron (2020) demonstrate how organizations ensure the ongoing production and promotion of rankings as a numerical observation of higher education institutions.

In the following, I will zoom in on the form of power and discipline that is exerted by governance based on numbers. Against the backdrop of Michel Foucault's socio-historical study on panopticism (Foucault, 1991), I will discuss different aspects of governance by numbers as panopticism.

\section{Governance by Numbers as Panopticism}

The contributions to this thematic issue create an overview of governance by numbers as an arrangement of discourses, devices, practices and infrastructures that facilitate the performance-oriented steering of higher education. This provides the opportunity to reflect again upon governance by numbers as a Foucauldian power-knowledge complex based on panoptical dispositifs (Foucault, 1977, p. 194). In doing so, my aim is to show how research on governance by numbers can benefit from a Foucauldian perspective on power and discipline, a perspective that is all but new to the study 
of quantification (cf. Mennicken \& Espeland, 2019) but which nonetheless brings issues to the fore that can complement the current contributions.

A panopticon is both a specific type of institutional building and a general system of control. Originally developed by the philosopher and social reformer Jeremy Bentham in the 18th century, panopticism received popular attention when Foucault used it as an analogy for the emergence of the modern disciplinary society (Foucault, 1991). Epitomizing a general principle that allows for the efficient exertion of power and discipline, the panopticon was the ideal metaphor for Foucault to explain how human complexities are ordered and individuals are inserted seamlessly into the social machinery. The classical panoptical architecture is realized in a circular building. The periphery of the rotunda is divided into cells with two windows: One that opens on the outside and allows the light to cross the cell from one side to the other, and another window that opens toward the center. In the center is a tower with windows that open toward the peripheral cells around it. The tower is occupied by an individual in task of surveying the separated, perfectly individualized cells. While each cell is constantly visible from the tower and the tower is visible from the cells, the inmates never know whether they are actually being observed at a specific point in time. The appeal that the panopticon had for contemporaries is (at least) twofold: First, there is no escape from the panoptic gaze. It can penetrate each cell. Second, power relations are automatized. They are upheld mechanically, without force, chains and dungeons.

Discussing governance by numbers as a form of panopticism, I join other scholars who have identified different forms of number-based panopticism. The increase of quantification and the centralization of the production, collection and analysis of numerical data have led to what has been described as statistical panopticism (Diaz-Bone, 2019). Based essentially on numerical information, statistical panopticism generates and accumulates huge masses of data, for example in the form of official statistics on unemployment or as data on health gathered by apps developed in insurance companies. The examples already convey that the potential of numberbased panopticism has exponentially increased due to technological developments. Consequently, information technology in the business sector has been described as an information panopticon that records and displays human behavior and thus provides the computer age with a new degree of transparency (Zuboff, 1988). Although similar to statistical panopticism, an information panopticon is not necessarily characterized by huge masses of data. It is usually limited to the workplace and thus geared more directly towards the managerial control of workers. The academic equivalent of the information panopticon in the business sector are numerocratic techniques of scientometrics, which exercise a power that aims to govern large populations of academics through numbers and standards (Angermuller \& van Leeuwen,
2018). Current digital information technologies have long potentiated the means of information panopticon. Digital archives from Google Scholar to academia.edu are deeply embedded in the social organization of the sciences. They form what has been coined a digital panopticon in which everybody can observe everybody elseand not least themselves (Angermüller, 2010).

Reflections on statistical, informational and digital panopticism have revealed important insights on governance based on numbers. Although it employs different foci, the literature illustrates that governance by numbers can be conceived as a panoptical dispositif of power and discipline. The literature shares the basic assumption that there are marked similarities between classical and contemporary panoptical dispositifs.

\section{Some Specifics of Numerocratic Panopticism}

The similarities between classical panopticism and governance based on numbers notwithstanding, I would like to stress three differences between the two panoptical dispositifs. This may specify the heuristic of panopticism and contribute to a clearer picture of what could be coined 'numerocratic panopticism,' a form of government in which the authority of numbers is exerted through panoptical power and discipline (cf. Angermuller \& van Leeuwen, 2018).

The first difference between classical and numerocratic panopticism concerns the way in which the observer and the observed are arranged in relation to each other. In the classical panopticon, observed subjects are locked in separated cells around a central tower from which they are observed. Numerocratic panopticism reverses this positional arrangement of the observer and the observed in two ways. First, the new positional arrangement does not lock up the observed in a peripheral cell, but places them in the center and surrounds them with observers. There is no single disciplining gaze emanating from the center. Rather, academic subjects are now observed by a number of different indicators and metrics. While the revolutionary potential of the classical panopticon is based on its ability to "reduce the number of those who exercise power" (Foucault, 1991, p. 206), numerocratic panopticism reverses this logic and increases the number of observers. In this regard, a heuristic of panopticism could complement Huber's (2020) contribution on financial quantification in universities, which attends to various types of numbers that are produced for a multiplicity of audiences. The second reversal of the positional arrangement of the classical panopticon is that the aim of numerocratic panopticism is not to isolate the observed in separated cells. Instead, the observed subjects can see each other, indeed, they are supposed to mutually observe, compare and discipline each other. In the numerocratic panopticon, the disciplining gaze does not only emanate from multiple observers but also from other observed subjects, and, finally, from each subject observing itself. University rank- 
ings, as analyzed by Ringel et al. (2020), are a prime example of this form of discipline.

Although Foucauldian panopticism is a general principle for the exertion of control and power, it has to be realized in spatial arrangements. Classical panopticism is dependent on a specific architectural form that has been adopted by disciplinary institutions like psychiatric asylums or penitentiaries. Governance based on numbers does not rely on such spatial constraints. Its realization neither depends on the spatial arrangements of buildings nor on the mutual physical presence of the observer and the observed in the same locality. Although indicators and metrics as well as the paper sheets and digital databases hosting them can have a material form, they are void of a specific spatial localization and do not require the individual to be "inserted in a fixed place" (Foucault, 1991, p. 197). To be sure, the formula for the spread of panopticism beyond enclosed spaces already lies in the panoptic principle itself and the spread of disciplinary institutions during the classical age. Yet, the reversal of the distinctively spatial arrangement of classical panopticism is only fully realized by omnipresent, non-spatial numerocratic panopticism that resembles a fluid network rather than an architectural form. The nonspatiality and omnipresence of governance by numbers is illustrated in the contributions by Krüger (2020) and Ringel et al. (2020) on data infrastructures and rankings, which are precisely located at the intersection of politics, economy, media and academia, interrelating different practices, organizations and research fields. A heuristic of panopticism could complement these contributions, revealing how panoptical dispositifs allow specific forms of power and discipline to permeate practices, organizations and fields.

As a third difference to classical panopticism, numerocratic panopticism is much more open regarding the specific purpose of observation and control. The ultimate rationale of the classical panopticon is "measuring, supervising and correcting the abnormal" in order "to train or correct individuals" (Foucault, 1991, pp. 199, 203). Crucially, this rationale is achieved because the observed can never be sure whether they are actually being observed, even though the tower is constantly visible. Numerocratic panopticism reverses this setting: First, subjects do know that they are being observed at any moment, that each action is tracked and filed. Yet, unlike the tower, the observing entity is not in plain sight but has diffused into algorithms, metrics and indicators. Second, it is much more difficult to pinpoint the purpose of individual observations. Observed subjects do not automatically know what each observer expects from them. What is more, some observations might bear no relevance at all for the observed. At the very least, it is an empirical question whether data collected by, for example, academia.edu has any impact on academics' everyday life. Contributions to this thematic issue emphasize this: They show that observers produce numbers without actually using them (Hillebrandt, 2020), that num- bers are produced without an explicit purpose (Kandiko Howson et al., 2020; Krüger, 2020), and that the purpose of observations can be challenged and contested (Dix et al., 2020). A heuristic of panopticism could complement these contributions by raising questions about the disciplining effects of observations that are more open regarding their specific purpose. A Foucauldian perspective suggests that this openness is precisely the foundation for the self-discipline of subjects that is already implied in the panopticon and fully developed in governmentality (Foucault, 2010).

\section{Conclusion}

Although classical and numerocratic panopticism share many similarities, I have proposed three features that distinguish them. Future research on governance by numbers can benefit from a heuristic of panopticism if it considers not only similarities, but also the differences between classical and numerocratic panopticism. First, numerocratic panopticism is multi-centered. Instead of a single observing entity, numerocratic panopticism is characterized by a multitude of different observers that have moved to the periphery. They surround the observed that is now placed in the center. Second, numerocratic panopticism is non-spatial. It is an omnipresent, fluid network that does not rely on specific spatial arrangements but permeates practices, organizations and fields. Third, numerocratic panopticism is open-purpose. The observed is not aware of the exact purposes of any individual observation, and some observations may be entirely insignificant to the observed. Crucially, these three distinct features of numerocratic panopticism reverse the respective features of the classical panopticon. This suggests that governance by numbers is not only an epitome of classical panopticism but, at least in some key aspects, also a panopticon reversed.

\section{Acknowledgments}

This comment has benefitted from discussions with Stefan Beljean, Rainer Diaz-Bone, Frank Meier and Thorsten Peetz during a meeting of the DFG research network "Towards a Society of Valuation?" I am also thankful for constructive feedback from the two academic editors and helpful comments from my colleagues at LCSS.

\section{Conflict of Interests}

The author declares no conflict of interests.

\section{References}

Angermüller, J. (2010). Wissenschaft zählen: Regieren im digitalen Panoptikum [Counting science: Governance in the digital panopticon]. In L. Hempel, S. Krasmann, \& U. Bröckling (Eds.), Sichtbarkeitsregime: Überwachung, Sicherheit und Privatheit 
im 21. Jahrhundert [Regimes of visibility: Surveillance, security and privacy in the 21st century] (pp. 174-190). Wiesbaden: Springer VS.

Angermuller, J., \& van Leeuwen, T. N. (2018). On the social uses of scientometrics: The quantification of academic evaluation and the rise of numerocracy in higher education. In R. Scholz (Ed.), Quantifying approaches to discourse for social scientists (pp. 89-119). London: Palgrave Macmillan.

Diaz-Bone, R. (2019). Statistical panopticism and its critique. Historical Social Research, 44(2), 77-102.

Dix, G., Kaltenbrunner, W., Tijdink, J., Valkenburg, G., \& de Rijcke, S. (2020). Algorithmic allocation: Untangling rival considerations of fairness in research management. Politics and Governance, 8(2), 15-25.

Foucault, M. (1977). The confession of the flesh. In C. Gordon (Ed.), Power/knowledge: Selected interviews \& other writings, 1972-1977, by Michel Foucault (pp. 194-228). New York, NY: Pantheon Books.

Foucault, M. (1991). Discipline and punish: The birth of the prison. New York, NY: Vintage Books.

Foucault, M. (2010). The government of the self and others: Lectures at the Collège de France 1982/83. New York, NY: Palgrave.
Hillebrandt, M. (2020). Keeping one's shiny Mercedes in the garage: Why higher education quantification never really took off in Germany. Politics and Governance, 8(2), 48-57.

Huber, M. (2020). Steered by numbers: How quantification differentiates the reform of a German university. Politics and Governance, 8(2), 26-35.

Kandiko Howson, C., \& Buckley, A. (2020). Quantifying learning: Measuring student outcomes in higher education in England. Politics and Governance, 8(2), 6-14.

Krüger, A. K. (2020). Quantification 2.0? Bibliometric infrastructures in academic evaluation. Politics and Governance, 8(2), 58-67.

Mennicken, A., \& Espeland, W. (2019). What's new with numbers? Sociological approaches to the study of quantification. Annual Review of Sociology, 45(2019), 223-245.

Ringel, L., Brankovic, J., \& Werron, T. (2020). The organizational engine of rankings: Connecting "new" and "old" institutionalism. Politics and Governance, 8(2), 36-47.

Zuboff, S. (1988). In the age of the smart machine: The future of work and power. New York, NY: Basic Books.

\section{About the Author}

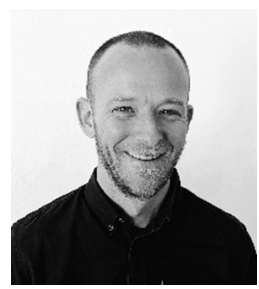

Julian Hamann is Postdoc at the Leibniz Center for Science and Society, Leibniz University Hannover, Germany. He is a Sociologist working in sociology of science and higher education research and at the crossroads of the sociologies of knowledge, culture and inequality. Recent research has been published in Social Studies of Science and American Journal of Cultural Sociology. 